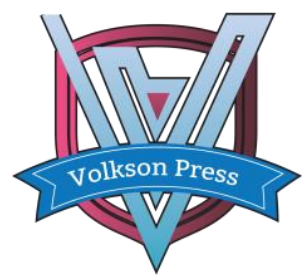

Contents List available at VOLKSON PRESS

\title{
Innovation and Development of Academic Library Service in the New Media Era*
}

Liu Yinhong

The Library of Wuhan University of Technology, Wuhan 430063, P. R. China

E-mail: lilaclyh@163.com

This is an open access article distributed under the Creative Commons Attribution License, which permits unrestricted use, distribution, and reproduction in any medium, provided the original work is properly cited.

\section{ARTICLE DETAILS}

\section{Article History:}

Received 02 october 2017 Accepted 06 october 2017 Available online 11 october 2017

\section{Keywords:}

Academic Library; Information Service; New Media; Innovation Strategies.

\section{ABSTRACT}

With the upcoming new media era, new challenges have been put forward to the academic library service. This paper analyzes the influence of new media on the service of academic library and puts forward the ways for academic library service. The objective is to build the New Media Environment to provide the efficient and personalized services for the readers.

\section{Introduction}

With the development of digital technology, network technology and mobile technology, human society has ushered in the new media era. New media is the perfect combination of network media and mobile media and makes full use of its advantages, by virtue of its fast spreading, various forms and contents of dissemination, to meet the social users' personalized and diversified knowledge needs. It has been widely concerned and used by people, especially in a hot pursuit by college students who have excellent acceptance and high sensitivity to the new affairs. Efficient library, as the school's literature information center, shoulders the responsibility to provide knowledge, information and inheriting human culture. In the new media era, the urgent problems for efficient library are how to adapt to the new environment, how to use new technologies and new means of innovative services and how to maximally meet the needs of users to achieve sustainable development.

\section{Characters of New Media and Its Influence on the Service of} Academic Library

\subsection{Digitization and Interactivity}

The new media is based on the digital technology and network technology, mainly on the basis of computer information processing technology. The Internet, satellite network, mobile communication are used as the media form of operation platform. Network technology and mobile technology are combined to form the new media such as mobile media, mobile TV, electronic newspapers, WeChat and microblog. Numbers, animation and sound can be integrated by the new media to illustrated transfer the information to the users. The digital information resources make the academic library information resources not only limited to the existing paper documents and electronic resources, but also include OA resources and institutional repository types of network resources, which covers search engine, database and network digital resources, etc. At the same time, multimedia technology and network technology, software, video, audio, image data has also become the important part of academic library collection under the new media environment. The constantly emergence of new media leads to a wide coverage of its content and increasingly diverse characteristics of its representation. The essence of new media is that everyone can be a producer and everyone is a communicator. Under the new media environment, the boundaries between the information communicators and the recipients are slowly melting. In the process of information dissemination, the user not only plays the role of information recipient, but also assumes the role of information publisher and communicator. The user can send information through SMS, Microblog, blog and social network platform no matter when and where. Two-way interactive communication can be realized through mass communication, and interactive is the unique charm of the new media. The digitization of information resources and the interaction of the new media make the way of user access to information resources diversified and widely, which greatly impacted the provision of academic library service.

\subsection{Demoralization and Immediacy}

The new media uses communication satellite and the Internet to transmit data, so the speed of information dissemination is very fast and it shows obvious real-time characteristic. It completely breaks the restrictions of cable network and region, internet users can release information quickly, receive information in time and spread information at any time through microblog, WeChat, blog, QQ and forums. In particular, the mobile phone new media, which can send and receive information quickly and has less restrictive factors, almost no restrictions of time and region, the user can search, check and publish information at any time and any place covered by the mobile internet network. Obviously, the traditional entity library resources cannot meet the users' needs for new media information.

\section{The Development of Academic Library Service under the New} Media Environment

For the academic library, with the popularization of the network, the quantity of users borrowing from the library decreases sharply, which results in the idleness of paper document resources. The status of the physical space gradually becomes weaken, and the library has gradually lost the central status of cultural in heritance-which then turns into the purchaser and supplier of information resources. With the emergence of the new media era, the form of information organization, the method of information acquisition have changed. The library must change the existing service pattern and carry out innovations from service concept, management mechanism, personnel training, service content and other aspects, thus breaking the shackle of traditional service and management, expanding the range of service in virtue of new media. So, users can obtain and use knowledge information more quickly and conveniently, making the academic library gets sustainable development.

\subsection{Innovating Service Concept, Establishing Knowledge Sharing System}

It can blend other service in the library by means of the core idea - "fusion" - of new media, giving full play to the characteristics of new media, integrating all services of the library, such as subject service, reference 
service, freshmen education, lectures of database, elective courses teaching of information literacy, promotion of digital reading and etc. Making use of media video resources, network promotion and other new publicity methods conduct the introduction of new books, information dissemination and the opening up of user forums. It is necessary to establish a knowledge sharing system to provide a platform for interaction of teachers and students, promote the sharing of information resources, find the potential information needs of college students and formulate a scientific guiding pattern.

\subsection{Adjusting Resources of Library Collection, Innovating Service Mode}

In recent years, downloads of digital resources in various universities library keep rising, while the borrowing amount of paper literature decrease gradually, even the reading room has the trend of turning into the study lounge. In such environment, adjusting the proportion of paper and digital resources, placing particular emphasis on the purchase cost of database and so on, can play the role of the collection resources. The surge of digital resources, the diversified development of user's access to information, which makes the medium that can be made use of turn into mobile, interactive and diverse style of the new media. Mobile library, mobile phone library, RSS information push service, microblog, WebChat, QR code scanning and SMS messaging services become the main trend of information service of academic library. Academic library service mode should be change into the diversified and interactive way by means of the advanced service concept and technical means, relying on library digital technology such as the WEB technology and the RSS technology. Carrying out system analysis according to needs, habits and preferences of different information users, providing intelligent information service, can push the library to users and set up an interactive network service platform based on the new media. It will realize the systematic, integrated use of information resources. Library can be converted to a digital academic community integration of knowledge collection, knowledge sorting, knowledge sharing, knowledge dissemination and knowledge discovery, then creating new library image.

\subsection{Cultivating Specialized Technical Personnel, Improving the Overall Quality of Librarians}

Users, resources (paper resources, electronic resources), equipment and management methods, management personnel are the indispensable three elements of library to achieve its own value. The emergence and widespread use of new media owes to the promotion of modern information technology, which requires the continuous improvement of the technology level of librarians to meet the service technology level of new media information. Furthermore, users have a higher demand to information needs of its universality, accuracy, authority and individuation under the new media environment, whose knowledgebased features are even more prominent. These put forward higher technical and quality requirements to the librarians in colleges and universities, to possess not only reasonable knowledge structure, strong business level, strong ability to control the information (including information collection, organization and ability of knowledge reconstruction), but also the ability to learn new technology and carry out innovation services in multiple forms. The academic library should strengthen the cultivation of talents with comprehensive quality, insuring information work personnel possess both technology and professional quality to adapt to the challenges of the new media environment.

\section{Conclusions}

In the new media era, information resources are in explosive growth, a variety of resources and books have been digitized. Users are not only satisfied to obtain literature material information, but more want to get the value of personalized information resources in deep mining. Therefore, the library staff should be required to have relevant professional knowledge, new media knowledge, network knowledge and information technology capability. Academic library should make good use of new technology and new media to change the service concept and service mode, and focus on improving the management level and staff's discipline professional service quality. Besides, it should change passive service to active promotion and meet the user's daily needs. Academic library should also expand new media channels and promote its special service through a variety of service platforms. Academic Library should carry out the online and offline activities and try to use new operation mode and service mode to provide efficient and personalized service for the user in order to promote and expand its service to a deeper and wider range.

\section{References}

[1] Zhao M. Research on the Innovation Service of University Library in Social Media Age. Library Work \& Study, Vol. 09(2016), pp125-128. (In Chinese)

[2] Hu B. Exploration of Reading Promotion Service Carried out by University Library Based on the New Media Era. Innovation Science \& Technology, Vol. 03(2016), pp85-87. (In Chinese)

[3] L. Wang. On the rise of the mobile media era and the service innovation of University Library. International Core Journal of Engineering, Vol. 1, No.4(2015), pp 30-33

[4] Peg Burnette. Mobile Technology and Medical Libraries: Worlds Collide[J]. Reference Librarian, 2011, 52(1):98-105.

[5] Wang Z. Research on Library Innovation Service in Micro-era. International Conference on Advances in Social Science, Humanities, and Management, (2014), pp439-441.

[6] Jie P Y, Polytechnic G P. Research on Library Service Innovation and Practice in Higher Vocational Colleges in Mobile Micro Era. Journal of Jincheng Institute of Technology, Vol. 01(2016), pp1-4. (In Chinese)

[7] Yue Q I. Study on Expending and Deepening of the Service of University Library Based on the New Media Environment. Sci-Tech Information Development \& Economy, Vol. 24(2015), pp70-72. (In Chinese)

[8] Schopfel J, Roche J, Hubert G. Co-working and innovation: new concepts for academic libraries and learning centres. New Library World, Vol. 116, No.1-2 (2015), pp67-78.

[9] Islam M A, Agarwal N K, Ikeda M. How does knowledge management affect service innovation in academic libraries?: A survey study[J]. Proceedings of the Association for Information Science \& Technology, Vol. 52, No. 1(2016), pp1-4. 